\title{
Post-harvest conservation of camu-camu fruits (Myrciaria dubia (Kunth) Mc Vaugh) using different temperatures and packages
}

\author{
Maria Luiza GRIGIO ${ }^{1 \star}$, Maria Fernanda Berlingieri DURIGAN ${ }^{1}$, Edvan Alves CHAGAS ${ }^{1}$, \\ Pollyana Cardoso CHAGAS ${ }^{1}$, Cassia Rejane do NASCIMENTO ${ }^{1}$, Maxwell Souza ALMEIDA ${ }^{1}$
}

\begin{abstract}
The camu-camu tree (Myrciaria dubia (Kunth) Mc Vaugh) is fruit-bearing tree belonging to the family Myrtaceae. This work was conducted with the purpose of evaluating the type of storage temperature and package which allow better conservation of the quality attributes of camu-camu. The experimental design utilized was the completely randomized with three replications in a factorial arrangement $(3 \times 3 \times 8)$, constituted of three different storage temperatures (laboratory ambiente or $25 \pm 2{ }^{\circ} \mathrm{C}, 15^{\circ} \mathrm{C}$ and $20^{\circ} \mathrm{C}$ ), three types of packages (no package, PET and PVC) and fourteen days' storage, the fruits being analyzed every two days. The fruits were evaluated as to fresh mass loss, $\mathrm{pH}$, soluble solids contents, titrable acidity, ascorbic acid, carotenoids, anthocyanins, chlorophylls A and B and maturation index (SS/AT). According to the results obtained, the quality attributes and ascorbic acid content were conserved for longer time in the fruits stored on PVC-film covered expanded polystyrene trays at $15{ }^{\circ} \mathrm{C}$. It follows that the best temperature for the storage of camu-camu is $15^{\circ} \mathrm{C}$ and the package that best keeps its quality attributes is the PVC-film covered expanded polystyrene tray.
\end{abstract}

Keywords: amazon fruit; ascorbic acid; refrigerated storage; quality; shelf-life.

Practical Application: The present study shows that the behavior of the camu-camu fruits during the refrigerated storage period, refrigerated or not and with different packages. Demonstrating which treatments best kept the fruits and their qualitative attributes as well as how each treatment influenced the shelf-life of these fruits.

\section{Introduction}

Camu-camu (Myrciaria dubia (Kunth) Mc Vaugh) is a typically Amazonian fruit, for it is a species of wide distribution on the banks of their lakes and rivers. Its geographical distribution is limited to the river course, stretching from the state of Pará (Rivers Tocantins and Trombetas) to Peru with the denomination of camu-camu. In Amazonia Central (Manaus and Manacapuru, on the rivers Javari, Madeira and Negro) and in Roraima, Brazilian states, it is found on the banks of natural lakes close to the Rio Cauamé, where it is known also with the denomination of caçari (Smiderle \& Sousa, 2008).

It presents a fruit bacaceous, globous, with a fleshy mesocarp (gelatinous) and whitish, of citric flavor; the skin coloration is pale-green as immature and ranges from dark-red to black-purple as ripe; and is 1.4 to $2.7 \mathrm{~cm}$ high, 1.6 to $3.10 \mathrm{~cm}$ in diameter and average weight of $8.4 \mathrm{~g}$. The number of seeds varies from 1 to 4 per fruit, are reniform with fibrils on their surface and present good agronomic, technological and nutritional traits (Yuyama, 2011; Maeda et al., 2006).

Its concentration of ascorbic acid (vitamin C) is 20 times as great as that of acerola and 60 times as great as that of lemon. Each 100 grams of its pulp have between 2.3 and 3 grams of vitamin $\mathrm{C}$ and the skin presents concentration still higher of up to 5 grams. It is the greatest natural source of ascorbic acid known. For containing a high ascorbic acid and citric acid content, camu-camu is a powerful anti-oxidant (Smiderle, 2009).

The growing interest for camu-camu fruits is due mainly to it outstanding vitamin $\mathrm{C}$ content, which in fruits coming from the eastern region of Roraima the average values of this vitamin were from 3.571 up to $7.355 \mathrm{mg} 100 \mathrm{~g}^{-1}$ of fresh pulp (Yuyama et al., 2002; Chagas et al., 2015), indicating that these fruits are the ones which present the greatest amount of ascorbic acid, at present. In addition to vitamin $\mathrm{C}$, camu-camu fruits also contain other antioxidant compounds as carotenoids, anthocyanins and other phenolic compounds which are furnished by their intake (Neves et al., 2015). Its high potassium content also suggests its indication for hypertense people, for it provides a better balance of salts in the organism, mainly in relation to sodium chloride (Menezes, 2001).

Nevertheless, those bioactive compounds such as vitamin $\mathrm{C}$ present a great instability and can be lost easily. According to Maeda et al. (2007) the concentration and the stability of vitamin $\mathrm{C}$ in camu-camu varies with the species, maturation stage, processing time and temperature, $\mathrm{pH}$, presence of oxygen and enzymes. The degradation of that compound can occur also during processing and/or storage. 
Camu-camu, like tropical fruits, has a relatively short useful lifetime as compared with the long-lasting grains and cereals. Perishable products such as vegetables, fruits, flowers and plants are alive and their metabolism active so that they respire, mature and senesce. Therefore, the conditions utilized for their packaging should allow the continuity of their vital process in a normal way (Chitarra \& Chitarra, 2005) aiming to slow down that metabolism. So, the use of post-harvest technologies like packages and refrigerated storage are widely used with the purpose of increasing the shelf-life of those products, minimizing losses.

The commercially most utilized packages are transparent pots of polyethylene terephthalate (PET) expanded polystyrene (isopor) covered with vinyl polychloride film (PVC). Nevertheless, the permeability and thickness of the films which cover the packages should be adequate to prevent fermentations by means of gas changes and allow fruit cooling (Pizarro, 2009).

According to Chitarra \& Chitarra (2005), use of refrigeration is essential to slow down metabolism and minimize the losses, which are faster at high temperatures due to the high metabolic rate, including losses of aroma, flavor, texture, color and other quality attributes. That rate should be kept at minimum level and enough to maintain the cells alive in order to preserve the quality of the products throughout the storage period.

So, it was intended in this work to evaluate the type of package and storage temperature which best conserves the quality attributes of camu-camu.

\section{Material and methods}

The camu-camu fruits utilized in the experiment were harvested from native plants localized in the bank of the River Jatapú, municipality of Caroebe, state of Roraima, Brazil, the geographical coordinates of reference of which are $02^{\circ} 27^{\prime} 45^{\prime \prime} \mathrm{S}$, $60^{\circ} 50^{\prime} 14^{\prime \prime} \mathrm{W}$. After harvest, the fruits were packed carefully in plastic boxes to prevent the fruits from being smashed and transported to the Embrapa-Roraima Post-harvest Laboratory, where they were selected as to the absence of damages and cleaned with $0,02 \%$ sodium hypochlorite $(\mathrm{NaClO})$ for 30 minutes, and then put to dry on the benches of the laboratory lined with paper towels.

After this step, the fruits were packed according to the following treatments: T1 (no package at laboratory room temperature, $25 \pm 2{ }^{\circ} \mathrm{C}$ and $70 \pm 5 \% \mathrm{RH}$ ); T2 (no package at $15^{\circ} \mathrm{C}$ and $70 \pm 5 \% \mathrm{RH}$ ); $\mathrm{T} 3$ (no package at $20^{\circ} \mathrm{C}$ and $70 \pm 5 \%$ $\mathrm{RH})$; T4 (PET package at $25 \pm 2{ }^{\circ} \mathrm{C}$ and $\left.70 \pm 5 \% \mathrm{RH}\right)$; T5 (PET package at $15^{\circ} \mathrm{C}$ and $\left.70 \pm 5 \% \mathrm{RH}\right) ; \mathrm{T} 6\left(\mathrm{PET}\right.$ package at $20^{\circ} \mathrm{C}$ and $70 \pm 5 \% \mathrm{RH}$ ); T7 (PVC film covered expanded polystyrene ray at $25 \pm 2{ }^{\circ} \mathrm{C}$ and $70 \pm 5 \% \mathrm{UR}$ ); T8 (PVC film covered polystyrene tray at $15^{\circ} \mathrm{C}$ and $70 \pm 5 \% \mathrm{RH}$ ); and T9 (PVC film covered expanded polystyrene tray at $20^{\circ} \mathrm{C}$ and $\left.70 \pm 5 \% \mathrm{RH}\right)$. The fruits of the treatments with temperatures at $15^{\circ} \mathrm{C}$ and at $20^{\circ} \mathrm{C}$ were stored in BOD's with controlled temperature and relative humidity, while the fruits stored in laboratory, the temperature control was done with use of air central $\left(25 \pm 2{ }^{\circ} \mathrm{C}\right)$.

The experimental design utilized was the completely randomized with three replications, in a factorial scheme $(3 \times 3 \times 8)$, constituted of three different storage temperature (laboratory temperature, $15^{\circ} \mathrm{C}$ and $20^{\circ} \mathrm{C}$ ), three types of packages (no, PET and PVC package) and 8 days' analysis $(0,2,4,6,8,10,12$ and 14 ), each replication being composed of 30 fruits (approximately $300 \mathrm{~g}$ of fruits).

The fruits were analyzed every two days, on each day of analysis, the plots were weighted for verification of the fresh mass loss an after that verification the seeds were withdrawn and the remaining material (pulp + skin) was processed and homogenized for conduction of analyses.

The analyses done were:

Fresh mass loss - the plots containing the fruits already ready and organized for storage were weighted on the days of the experiment installation. Every two days that weight was again verified and the results expressed at \% of lost fresh mass in relation to initial weight.

pH (potential of hydrogen) - the methodology of Adolfo Lutz Institute - IAL (Instituto Adolfo Lutz, 2008) was followed and this analysis was conducted with pHmeter, the electrode of which was dipped in the processed sample.

Soluble Solids (SS) - This content was determined by refractometry by utilizing a portable refractometer. The analysis was done in the homogeneous filtrate of the ground material obtained by its separation of the solid parts of the fruit with the results expressed at ${ }^{\circ}$ Brix (Instituto Adolfo Lutz, 2008).

Titrable acidity (AT) - Determined according to the methodology described by Adolfo Lutz Institute (Instituto Adolfo Lutz, 2008). The results were expressed in $g$ of citric acid $100 \mathrm{~g}^{-1}$ of pulp.

Maturation index ('Ratio') - Calculated by the ratio between the contents of SS and AT.

Ascorbic Acid (AA) - The content of this acid was determined by the Tillmans method (Instituto Adolfo Lutz, 2008). The results were expressed at $\mathrm{mg}$ of ascorbic acid $100 \mathrm{~mL}^{-1}$ of sample.

Carotenoids - The determination of the carotenoid content was done following the methodology of Linder (1974) and Whitham et al. (1971), with the aid of a pipette and the reading of the absorbance was performed in a spectrophotometer at $470 \mathrm{~nm}$. The results were expressed at $\mu \mathrm{g} 100 \mathrm{~g}^{-1}$ of fresh pulp.

Anthocyanins - The determination of the anthocyanin content was done following the methodology by Linder (1974) and Whitham et al. (1971), with absorbance reading conducted in a spectrophotometer at $537 \mathrm{~nm}$. The results were expressed at $\mu \mathrm{g} 100 \mathrm{~g}^{-1}$ of fresh pulp.

Chlorophyll A - The determination of the A chlorophyll content was also done following the methodology by Linder (1974) and Whitham et al. (1971) with spectrophotometric reading at $663 \mathrm{~nm}$ and the results expressed at $\mu \mathrm{g} 100 \mathrm{~g}^{-1}$ of fresh pulp.

Chlorophyll B - The quantification of chlorophyll B was done utilizing the methodology by Linder (1974) and Whitham et al. (1971) with spectrophotometric reading at $647 \mathrm{~nm}$ and the results expressed at $\mu \mathrm{g} 100 \mathrm{~g}^{-1}$ of fresh pulp. 
The data obtained of each evaluation day were submitted to the analysis of variance by the $\mathrm{F}$ test at $5 \%$ and to the analysis of polynomial regression utilizing the SISVAR program (Ferreira, 2007).

\section{Results and discussion}

According to the results obtained for all the variables, the interactions tested presented significant effect by the $\mathrm{F}$ test at $5 \%$ of probability, except the triple interaction. As regards the evaluated pigments, chlorophyll B contents were not detected in the fruits throughout the storage period. There was no regression fitting in the tested models for the pigments anthocyanin and carotenoid as well as for the interactions: days $\mathrm{x}$ temperatures for the variables acidity and maturation index and days $\mathrm{x}$ pacakges for the variable $\mathrm{pH}$. Anthocyanins and carotenoids variables were average values of 761.1 and $182.6 \mu \mathrm{g} 100 \mathrm{~g}^{-1}$ of fresh pulp, respectively.

The fruits stored at laboratory ambiente temeprature $\left(25 \pm 2{ }^{\circ} \mathrm{C}\right)$ on the tenth day of storage were no longer suitable for for consumption and from thsi day on the fermentation signals of these fruits were already apparent. So, from the tenth day on, those fruits were no longer evaluated.

The fresh mass loss proved linear and growing in all the packages tested, the greatest means were found in the fruits stored with no package at all. These values at the end of the experiment indicated fresh mass loss of about 15\% (Figure 1). The fruits stored in the PET and PVC packages at the end of the experiment presented $8 \%$ and $9 \%$ of mass loss, respectively. This stresses the importance of the use of packages to increase the shelf-life of fruits, minimizing losses both qualitative and quantitative during storage.

In evaluating the tested packages, it is notorious that the PET package was the one which best kept the fruits' moisture, reducing thus the mass loss that at the end of the experiment presented an average value of $12 \%$. Whereas in testing the PVC package at the end of the storage period, the losses reached about $20 \%$. Similar results were found by Morgado et al. (2010) who working with guavas 'Kumagai', verified that in the guavas stored at $21^{\circ} \mathrm{C}$, the mass loss was more marked and faster than in the fruits stored at lower temperatures.

The fruits stored under different temperatures also presented linear and growing response when the variable fresh mass loss without nay difference between those stored at $25 \pm 2{ }^{\circ} \mathrm{C}$ and at $20^{\circ} \mathrm{C}$, in which at the end of the experimental period, the fruits already were wilt and with loss of turgescence, brightness and coloration. But, in the fruits stored at $15^{\circ} \mathrm{C}$ this loss was significantly smaller where the same ones kept a better appearance for a longer period. The fruits stored at the temperature of $25 \pm 2{ }^{\circ} \mathrm{C}$ from the tenth day's storage were no longer suitable for consumption and with signals of fermentation and because of this reason they were not evaluated (Figure 1). That is, both the use of packing as the most significant effect at low temperatures and better preserved fruits during storage days.

As regards the variable $\mathrm{pH}$, the fruits stored at $15{ }^{\circ} \mathrm{C}$ and at $20^{\circ} \mathrm{C}$ presented similar behavior with an increase of about
$14 \%$ in the $\mathrm{pH}$ values, which can be related to the water loss of fruits (Figure 2). The fruits stored at temperature of $25 \pm 2{ }^{\circ} \mathrm{C}$ presented a similar variation similar till the sixth day when the values decreased likely due to the fermentative process and, for this reason, the abrupt reduction or with around $26 \%$ in the $\mathrm{pH}$ values. Therefore, the low temperatures interact significantly with days of storage, showing an increase with each passing day.
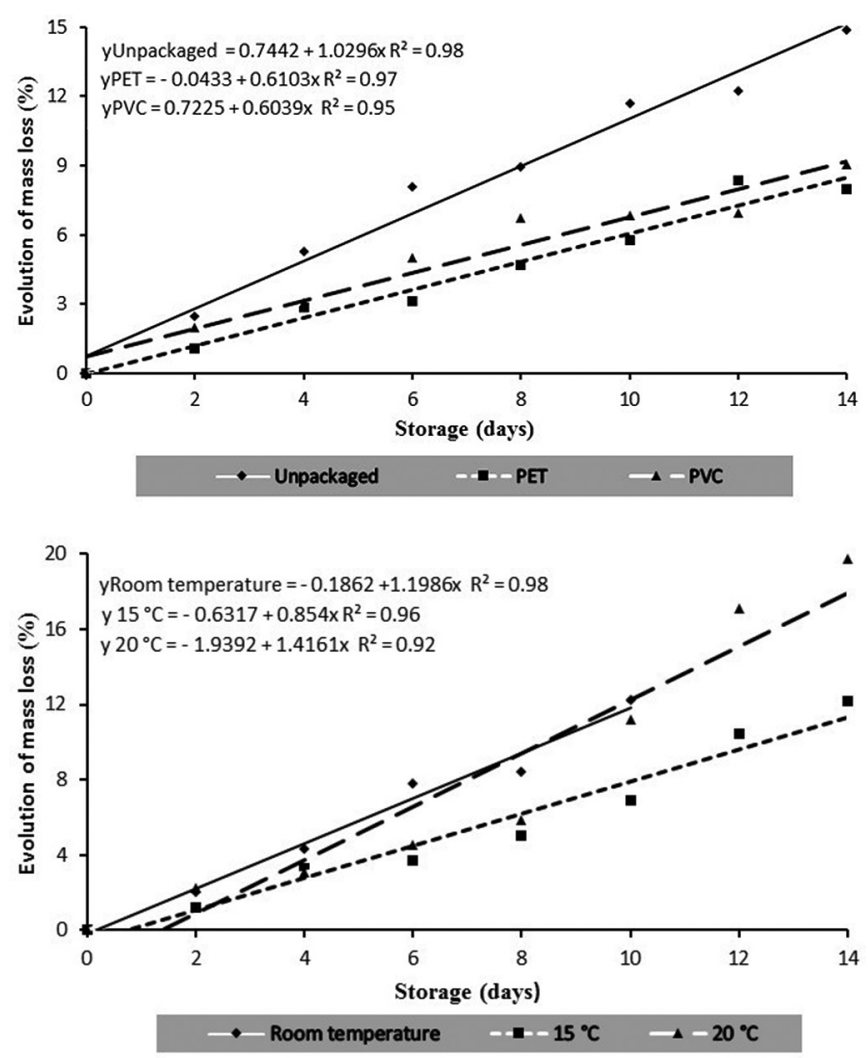

Figure 1. Evolution of mass loss in camu-camu fruits packed in different types of packages and stored under different temperatures. Roraima, 2015.

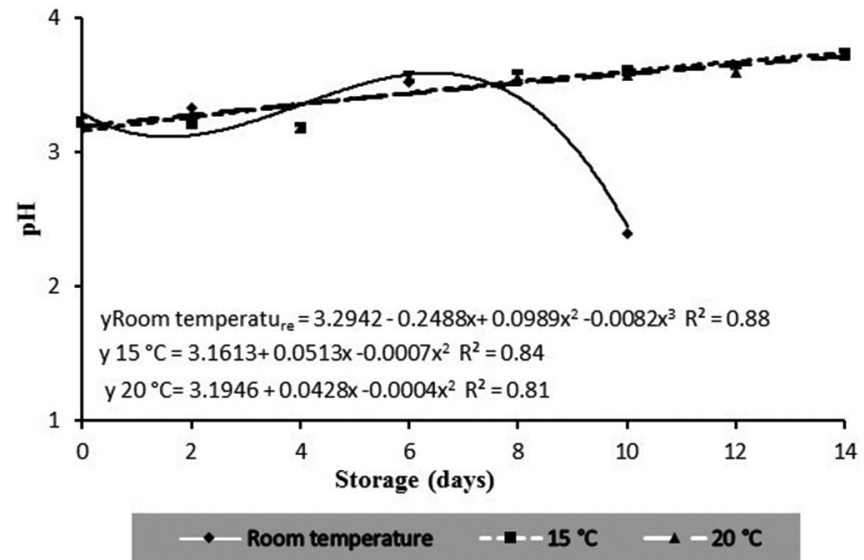

Figure 2. Potential of hydrogen $(\mathrm{pH})$ of the camu-camu fruits packed in different types of packages and stored under different temperatures. Roraima, 2015. 
According to Chitarra \& Chitarra (2005), the use of refrigeration delays the deteriorations preserving lower metabolic rates and, consequently lesser losses of aroma, flavor, texture, color and other quality attributes.

The soluble solids content presented increase between the fourth and sixth day of storage with later decrease in those values. Nevertheless, at the end of the experiment the fruits with no package still presented values of soluble solids higher than in the other treatments (Figure 3). Jacomino et al. (2000) ascribed the increase in the soluble solids content to mass loss, causing the concentration of sugar in the pulp to increase, explaining the greater contents in eh fruits stored with no package.

The fruits stored in PET and PVC packages presented similar behavior, where from the sixth day; the values of soluble solids began to decrease. Possibly, those compounds would be being used as a source of energy for all the metabolic transformations occurred in these plant tissues, which kept active, towards senescence. This fact highlights the importance of using low temperatures and use of packaging on postharvest conservation of fruit camu-camu.

The fruits stored at $15^{\circ} \mathrm{C}$ and at $20^{\circ} \mathrm{C}$ presented increase in the soluble solids content in the six first days of storage, with later smaller decrease, as compred with the fruits stored at temperature of $25 \pm 2{ }^{\circ} \mathrm{C}$ which also presented initial increase in the soluble solids content till the fourth day of storage, from where were
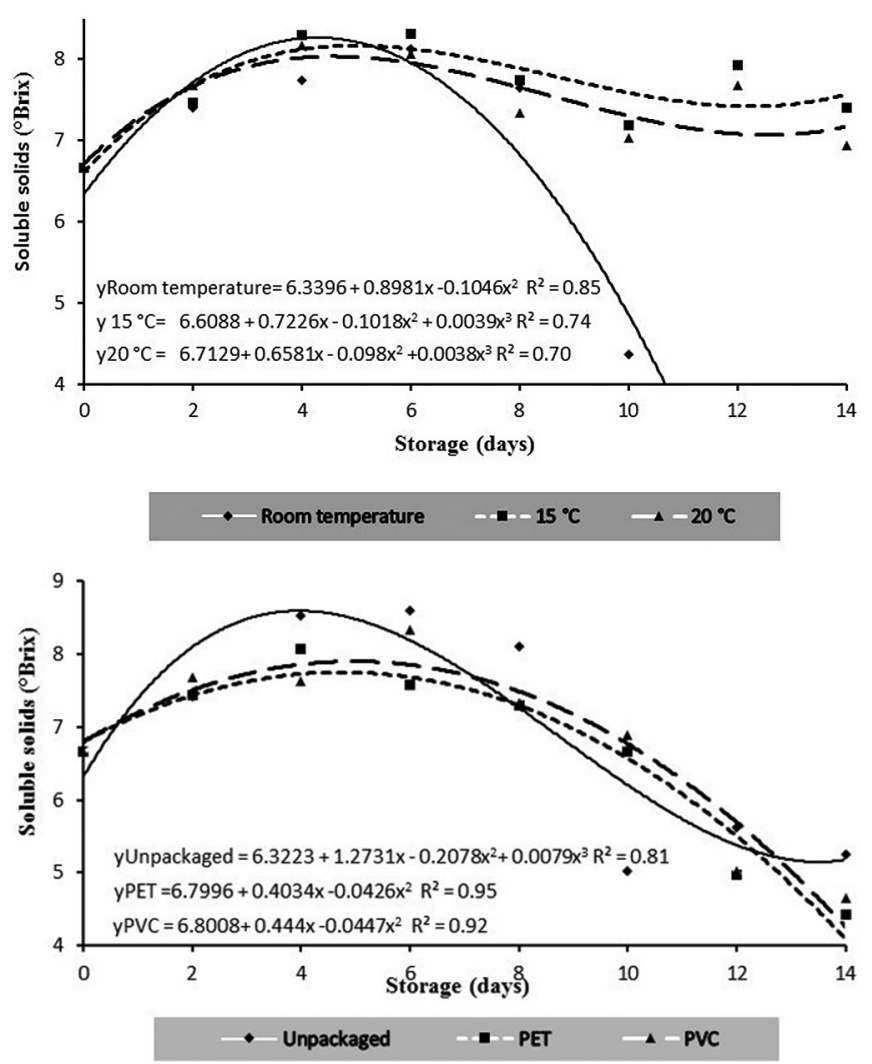

Figure 3. Soluble solids content in camu-camu fruits packed at different types of packages and stored under different temperatures. Roraima, 2015. found marked decreases (Figure 3 ). The storage at $15^{\circ} \mathrm{C}$ was the best kept the solubel solids content in camu-camu fruits.

The marked reduction of the soluble solids content in fruits under higher temperatures is due to the fact for these molecules to be being used as a fermentative substrate, indicating that the fruits were at senescence phase, indicated by the strong fermentative aroma from the tenth day on. This justifies the need of using refrigeration, not only to keep the quality but also for the reduction of the qualities losses. Nevertheless, the values found in the present wok are superior to the average values found by Akter et al. (2011), which are not higher than $6.4^{\circ}$ Brix.

As regards titrable acidity, all the treatments tested presented a small initial increase, which $\mathrm{cn}$ be realted to the mositure loss of fthe fruits, causing the amount of organic acids to become more concentrated with later decrease from 4-6 days on (Figure 4). The average value of acidity was of $3.38 \mathrm{~g}$ of acid $100 \mathrm{~g}^{-1}$ of pulp, which is superior to those found by other authors (Rufino et al., 2009; Akter et al., 2011). Probably, the greatest values are due to the fact that in this work the processed samples contained both pulp and skin.

Acidity loss is related to the natural process of maturation and senescence of fruits, which is also pointed out by Chitarra \& Chitarra (2005), for, organic acids would be serving as an energy source for the metabolic transformations occurred in these plant tissues (Grigio et al., 2011).
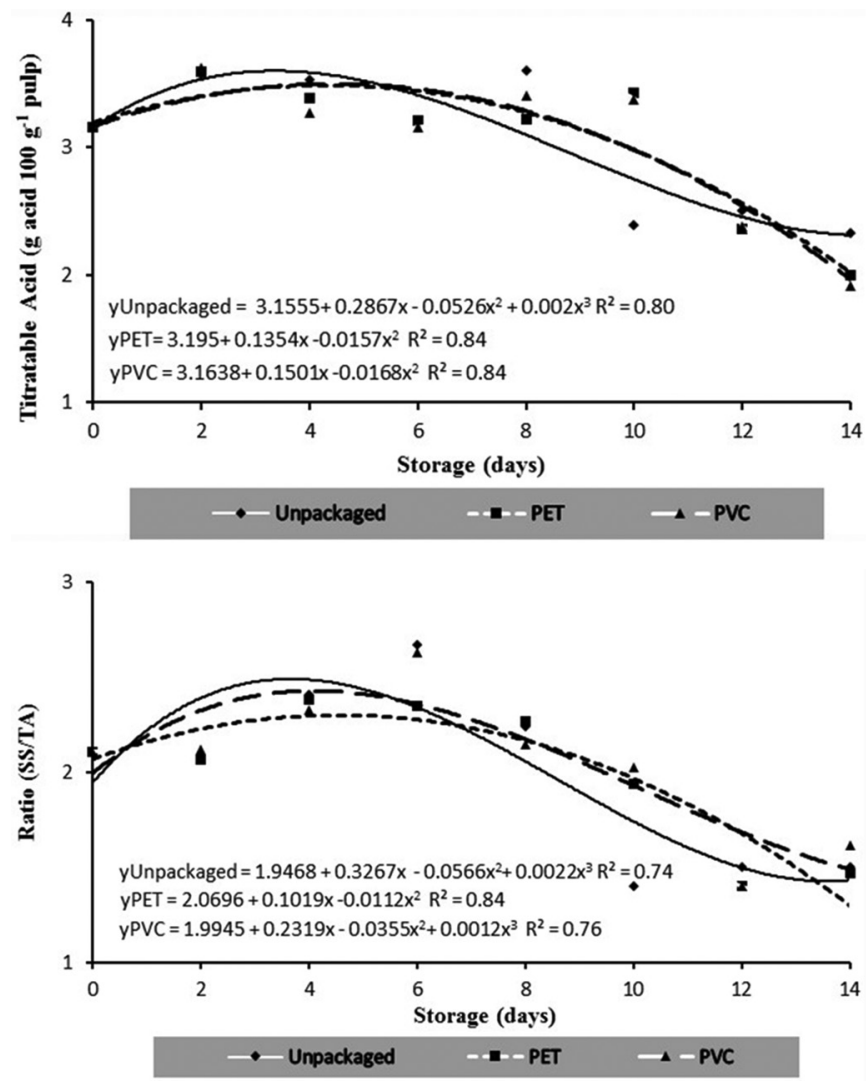

Figure 4. Titrable acidity content and maturation index or 'Ratio' (SS/TA) in camu-camu fruits packed in different types of packages and stored under different temperatures. Roraima, 2015. 
The ratio between soluble solids and titrable acidity (SS/AT) is one of the forms utilized for the evaluation of flavor, for it gives an idea of the balance between the sweetish and acidic flavors in fruits (Castillo-Pizarro, 2009). That variable also presented in the beginning of the storage, a slight increase, with later decrease (Figure 4). In the stored fruits with no package, the greatest increase occurred on the fourth day of storage, caused by the increase of the soluble solids content.

The results observed were lesser than those verified by Rufino et al. (2009) due to the greater acidity, since homogenate of pulp + skin was analyzed.

The amount of ascorbic acid camu-camu fruits packed in different packages presented an increase in the first two days' storage with later decrease till the end of the experiment (Figure 5). In the fruits stored with no package, this decrease was more marked, i.e., the lack of package caused greater losses to occur. Use of packages kept better that quality attribute, with the fruits stored in PVC package, presenting the greatest mean over the experiment, $5,000 \mathrm{mg} 100 \mathrm{~mL}^{-1}$ of pulp, followed by the fruits stored in PET package with no protection, com 4,866 and $4,750 \mathrm{mg} 100 \mathrm{~mL}^{-1}$ of pulp, respectively.

In all the treatments, there was decrease of the ascorbic acid contents, but in the treatment with PVC film, the decrease was lesser, indicating better conservation of camu-camu fruits and better maintenance of their physiological and nutritional characteristics. Similar behavior was found by Yamashita et al.
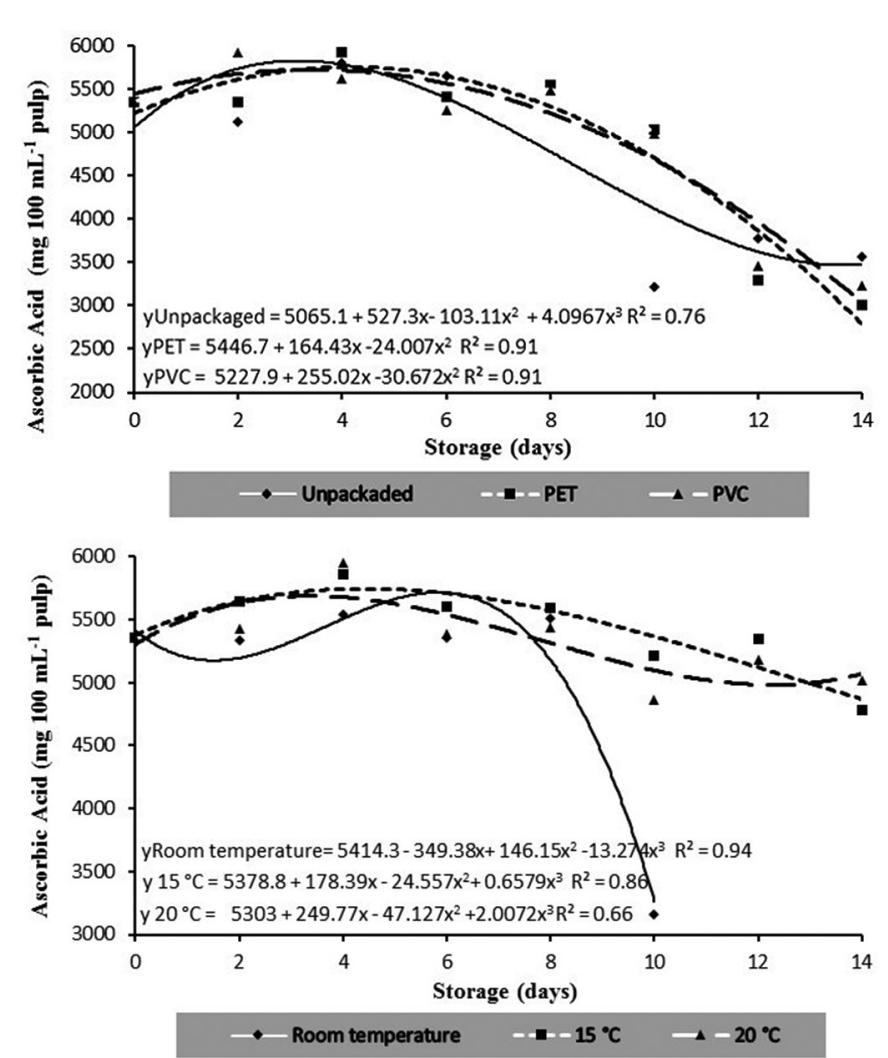

Figure 5. Ascorbic acid content in camu-camu fruits packed in different types of packages na stored under different temperatures. Roraima, 2015.
(2006), who worked with strawberries stored in different sorts of packages.

In quantifying the ascorbic acid content in the camu-camu fruits stored under different temperatures, all the tested treatments presented decreases (Figure 5). Nevertheless, the fruits stored at $15{ }^{\circ} \mathrm{C}$ were the ones which best maintained ascorbic acid contents. It was found also that the fruits stored at the temperature of $25 \pm 2{ }^{\circ} \mathrm{C}$ presented a marked decrease from the sixth day' storage, which possibly is due to senescence, which was pointed out by the fermented smell from the tenth day of storage onwards. Nevertheless, the values observed in this work were higher than those observed by Rufino et al. (2010), who detected average values of $1,882 \mathrm{mg} 100 \mathrm{~mL}^{-1}$ of pulp.

Calegaro et al. (2002) also found decrease in the ascorbic acid contents in stored strawberries and consider ascorbic acid as being the vitamin most susceptible to degradation, and that its presence and conservation in foods and fruits indicate that, likely, the other nutrients are also being preserved.

The chlorophyll A contents in the fruits stored in different packages presented increase on the first four days of storage with later decrease till the end of the experimental period (Figure 6) ascribed to ripening. The greatest means were observed in the fruits stored with no package with $43.09 \mu \mathrm{g} 100 \mathrm{~g}^{-1}$ of pulp, followed by the PVC and PET treatments with 40.74 and $40.46 \mu \mathrm{g} 100 \mathrm{~g}^{-1}$ of pulp, respectively, which had their ripening delayed. Published studies ascribe to plant extracts, antimutagenic
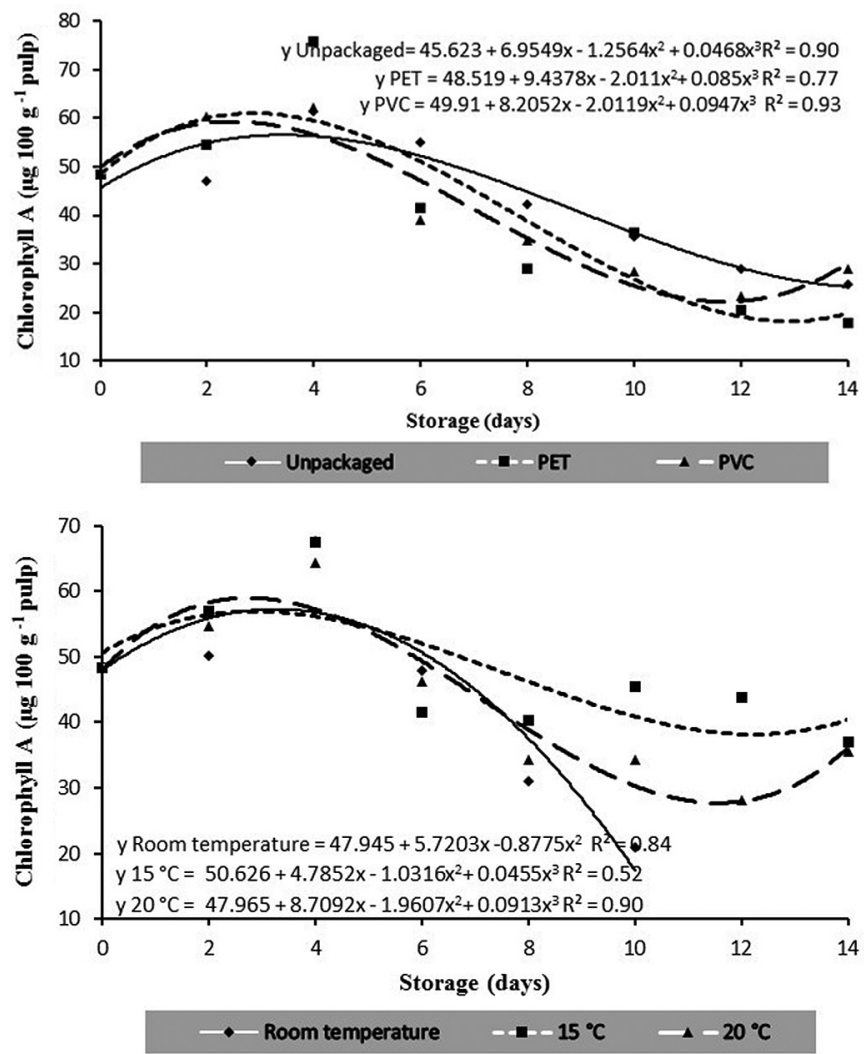

Figure 6. Chlorophyll A content of camu-camu fruits packed in different sorts of packages and stored under different temperatures. Roraima, 2015. 
and anticancer effects of chlorophyll, since these are related often to antioxidant activity, though by an indirect mechanism (Lanfer-Marquez, 2003).

Similar behavior was also observed in the fruits stored under different temperatures (Figure 6). The fruits stored at $15^{\circ} \mathrm{C}$ were the ones which presented the highest means $\left(47.62 \mu \mathrm{g} 100 \mathrm{~g}^{-1}\right.$ of pulp), followed by the treatments stored at $25 \pm 2$ and at $20^{\circ} \mathrm{C}$, with 44.37 and $43.28 \mu \mathrm{g} 100 \mathrm{~g}^{-1}$ of pulp, respectively.

According to Lanfer-Marquez (2003), there are few scientific works relating the intake of chlorophyll with some effect beneficial to human health, nevertheless, advertisements that chlorophyll would bring benefits over practically all the tissues, organs and systems of the human organisms, especially as the prevention of coronary diseases, certain kinds of cancers diabetes and cataract are concerned, have been conveyed.

As regards the anthocyanin and carotenoid contents, average values of 794.37 and $190.6 \mu \mathrm{g} 100 \mathrm{~g}^{-1}$ of pulp, respectively were found. Values higher than those detected in the present scientific investigation were detected by other authors. Rufino et al. (2010) detected average values of anthocyanins of $4,220 \mu \mathrm{g} 100 \mathrm{~g}^{-1}$. While, Zanatta \& Mercadante (2007), in verifying the carotenoid content of camu-camu fruits coming from Iguape and Mirandópolis detected average values of 354.8 and $1095.3 \mu \mathrm{g} 100 \mathrm{~g}^{-1}$ of pulp.

\section{Conclusions}

The quality attributes (SS, AT, $\mathrm{pH}$ and SS/AT) are conserved for longer in the fruits stored on PVC film covered expanded polystyrene tray and at $15^{\circ} \mathrm{C}$ as well as the ascorbic acid contents.

The contents of the pigment chlorophyll A present greater values in the camu-camu fruits stored with no package and at $15^{\circ} \mathrm{C}$. The quoted treatment also minimizes the fresh mass loss.

For the conservation of the quality attributes of camu-camu, the best storage temperature is $15^{\circ} \mathrm{C}$ and the package that best conserves these attributes is the PVC film covered expanded polystyrene tray.

\section{References}

Akter, M. S., Oh, S., Eun, J. B., \& Ahmed, M. (2011). Nutritional composition and health promoting phytochemicals of camu-camu (myrciaria dubia) fruit: a review. Food Research International, 44(7), 1728-1732. http://dx.doi.org/10.1016/j.foodres.2011.03.045.

Calegaro, J. M., Pezzi, E., \& Bender, R. J. (2002). Utilização de atmosfera modificada na conservação de morangos em pós-colheita. Pesquisa Agropecuaria Brasileira, 37(8), 1049-1055. http://dx.doi.org/10.1590/ S0100-204X2002000800001.

Castillo-Pizarro, C. A. (2009). Avaliação de morangos submetidos a resfriamento rápido e armazenamento em diferentes embalagens e temperaturas. (Tese de doutorado). Universidade Estadual de Campinas, Campinas.

Chagas, E. A., Lozano, R. M. B., Bacelar-Lima, C. G., Garcia, M. I. G., Oliveira, J. V., Souza, O. M., Morais, B. S., Chagas, P. C., \& Araújo, M. C. R. (2015). Variabilidade intraespecífica de frutos de camu-camu em populações nativas na Amazônia Setentrional. Crop Breeding and Applied Biotechnology, In press.
Chitarra, M. I. F., \& Chitarra, A. B. (2005). Pós-colheita de frutos e hortaliças: fisiologia e manuseio (2 ed.). Lavras: Universidade Federal de Lavras.

Ferreira, D. F. (2007). Sisvar: Versão 5.1 (Build 72). Lavras: DEX/UFLA.

Grigio, M. L., Neves, L. C., Tosin, J. M., Nascimento, C. R., Chagas, E. A., Vieites, R. L. (2011). Efeito da modificação atmosférica em goiabas var. Paluma na redução de danos mecânicos em póscolheita. Revista Agro@mbiente On-line, 5(1), 57-65. http://dx.doi. org/10.18227/1982-8470ragro.v5i1.406.

Instituto Adolfo Lutz - IAL. (2008). Normas Analíticas, métodos químicos e físicos para análise de alimentos (3 ed.). São Paulo: IAL.

Jacomino, A. P., Sarantópoulos, C. D. I. L., Sigrist, J. M. M., Kluge, R. A., \& Minami, K. (2000). Armazenamento de goiabas 'Kumagai' sob diferentes temperaturas de refrigeração. Brazilian Journal of Food Technology, 1(3), 165-169.

Lanfer-Marquez, U. M. (2003). O papel da clorofila na alimentação humana: uma revisão. Revista Brasileira de Ciências Farmacêuticas, 39(3), 227-242. http://dx.doi.org/10.1590/S1516-93322003000300003.

Linder, S. (1974). A proposal for the use of standardized methods for chlorophyll determinations in ecological and ecophysiological investigations. Physiologia Plantarum, 32(2), 154-156. http://dx.doi. org/10.1111/j.1399-3054.1974.tb03743.x.

Maeda, R. N., Pantoja, L., Yuyama, L. K. O., \& Chaar, J. M. (2006). Determinação da formulação e caracterização do néctar de camucamu (Myrciaria dubia Mc Vaugh). Ciência e Tecnologia de Alimentos, 26(1), 70-74. http://dx.doi.org/10.1590/S0101-20612006000100012.

Maeda, R. N., Pantoja, L., Yuyama, L. K. O., \& Chaar, J. M. (2007). Estabilidade de ácido ascórbico e antocianinas em néctar de camucamu (Myrciaria dubia (H. B. K.) Mc Vaugh). Ciência e Tecnologia de Alimentos, 27(2), 313-316. http://dx.doi.org/10.1590/S010120612007000200018.

Menezes, H. C. (2001). Saudável camu-camu. Pesquisa Revista Fapesp, 64-65.

Morgado, C. M. A., Durigan, J. F., Lopes, V. G., \& Santos, L. O. (2010). Conservação pós-colheita de goiabas 'Kumagai': efeito do estádio de maturação e da temperatura de armazenamento. Revista Brasileira de Fruticultura, 32(4), 1001-1008. http://dx.doi.org/10.1590/S010029452010000400008.

Neves, L. C., Silva, V. X., Pontis, J. A., Flach, A., \& Roberto, S. R. (2015). Bioactive compounds and antioxidant activity in preharvestcamu-camu [Myrciaria dubia (H.B.K.) Mc Vaugh] fruits. Scientia Horticulturae, 186, 223-229. http://dx.doi.org/10.1016/j. scienta.2015.02.031.

Pizarro, C. A. C. (2009). Avaliação de morangos submetidos a resfriamento rápido e armazenamento em diferentes embalagens e temperaturas (Tese de doutorado). Universidade Estadual de Campinas, Campinas.

Rufino, M. S. M., Alves, R. E., Brito, E. S., Silveira, M. R. S., \& Moura, C. F. H. (2009). Quality for fresh consumption and processing of some non-traditional tropical fruits from Brazil. Fruits, 64(6), 361370. http://dx.doi.org/10.1051/fruits/2009032.

Rufino, M. S. M., Alves, R. E., Brito, E. S., Pérez-Jiménez, J., SauraCalixto, F., \& Mancini-Filho, J. (2010). Bioactive compounds and oxidant capacities of 18 non-traditional tropical fruits from Brazil. Food Chemistry, 121(4), 996-1002. http://dx.doi.org/10.1016/j. foodchem.2010.01.037. 
Smiderle, O. J. (2009). Camu-camu: fruto amazônico com mais vitamina C que o limão. Viçosa: Portal do Agronegócio. Retrieved from: http://www.portaldoagronegocio.com.br/conteudo.php?id=33246

Smiderle, O. J., \& Sousa, R. C. P. (2008). Teor de vitamina C e características físicas do camu-camu em dois estádios de maturação. Revista Agro@ mbiente On-line, 2(2), 61-63.

Whitham, F. H., Blaydes, D. F., \& Devlin, R. M. (1971). Experiments in plant physiology (pp. 55-58). New York: D. Van Nostrand Company.

Yamashita, F., Veiga, G. F., Benassi, M. T., \& Roberto, S. R. (2006). Morangos embalados com filme de Policloreto de Vinila (PVC). Semina: Ciências Agrárias, 27(3), 429-436.
Yuyama, K. (2011). A cultura de camu-camu no Brasil. Revista Brasileira de Fruticultura, 33(2), i-ii. http://dx.doi.org/10.1590/ S0100-29452011000200001.

Yuyama, K., Aguiar, J. P. L., \& Yuyama, L. K. O. (2002). Camu-camu: um fruto fantástico como fonte de vitamina C. Acta Amazonica, 32(1), 169-174. http://dx.doi.org/10.1590/1809-43922002321174.

Zanatta, C. F., \& Mercadante, A. Z. (2007). Carotenoid composition from the Brazilian tropical fruit camu-camu (Myrciaria dubia). Food Chemistry, 10(4), 1526-1532. http://dx.doi.org/10.1016/j. foodchem.2006.04.004. 